\title{
Impact of New Standard "IFRS 16 Leases" on Statement of Financial Position and Key Ratios: A Case Study on an Airline Company in Turkey
}

\author{
Meryem Öztürk ${ }^{\mathrm{a}}$
}

\author{
Murat Serçemeli ${ }^{b}$
}

\begin{abstract}
The studies regarding the changes made related to the accounting for lease have taken its final status with the publication of IFRS16 Lease Standard as a result of a long time and effort in January 2016. The related Standard shall ensure (1) the reporting of all the leases in the same way, (2) the displaying of the unrecorded leases in the financial statements and therefore, (3) the submission of more transparent, correct and comparable information. The purpose of our study is to examine the statement of financial position of the lessee enterprise after the transition to the new financial reporting standard IFRS 16 and the impacts of the change in the basic ratios. For this purpose, the impacts possible to occur in the financial position of an airline company having activities in Turkey as a result of the application of the related standard have been examined. The results of the study show that the reflection of the operating leases on the balance sheet shall cause to significant increases in the assets and liabilities and for this reason; there shall be a significant increase in the ratio of liability/asset and a significant decrease return on asset.
\end{abstract}

Keywords: IFRS16, IAS 17, Operating Leases, Financial Leases, Off Balance Sheet Financing

JEL Classification: M40, M41, M48

\section{Introduction}

Increasing the reliability and transparency of the financial statements has recently become an issue on which emphasis have been laid. Although the International Financial Reporting Standards (IFRS) make significant contributions to the issue of the transparency, reliability and comparability of the companies, there are still distances to be covered. IAS 17 Lease Standard taking place among the IFRS has been criticized by the financial statement users due to the fact that financial statements of the companies having significant operating leases do not completely reflect the truth; because, the related Standard gives freedom to the IFRS implementing companies in the determination of their leases as operating or financial lease and this situation forms an important difference in the preparation of the financial statements. When a company classifies its leases as operating lease, the leased asset cannot be seen in the balance sheet of the company and the rental payments that belong to the operating leases are shown as expense in the income statement. Not showing the operating leases in the balance sheet causes the liabilities and profitability of the company to be seen less than it should be. Due to the reasons mentioned above, the need for the establishment of a new standard regarding the leases has occurred and the new standard IFRS 16 related to the leases has been published in

${ }^{a}$ Assist. Prof., PhD., Ataturk University, Open Education Faculty, Erzurum, Turkiye, meryemozturk@atauni.edu.tr

${ }^{b}$ Assist. Prof., PhD., Giresun University, Faculty of Economics and Administrative Science, Giresun, Turkiye, muratsercemeli@gmail.com 
January 2016 and will be applied starting from 2019. The new standard shall terminate the distinction between operating lease and financial lease in terms of the lessee and shall ensure the visibility of all the leases in the balance sheet.

In a study conducted by White (2015), the annual lease amount realized in the greatest 50 countries of the world in 2013 has been detected as 883.96 billion dollars and this amount has been detected as 5.68 billion dollars in Turkey in the same period. These figures are the indicators of the fact that the unrecorded leases could have a great importance. Within this scope; our purpose in this study is to examine the impacts of the new lease standard IFRS 16 on the statement of financial position and some important financial ratios of an airline company ${ }^{1}$ having activities in Borsa İstanbul in Turkey ${ }^{2}$.

Firstly, the literature review studies shall be given place in the study and after that, the changes brought by IFRS 16 shall be examined. Following this, the impacts of IFRS 16 on the statement of financial position and financial ratios of an airplane company shall be examined.

\section{Literature Review}

While reviewing the literature, it has been seen that many studies have been conducted regarding the leases. In this study, especially the studies examining the impacts of the capitalization of the unrecorded lease proceedings on the financial position and financial ratios of the companies have been given place.

In the study conducted by Imhoff et.al. (1991) for the purpose of revealing the importance of operating lease liabilities on the commonly used risk and performance scales, they have applied the method of constructive lease capitalization they have developed themselves in the capitalization of the unrecorded leases and examined its impacts on the assets and liabilities of McDonald's. The ratio of the unrecorded assets to the unrecorded liabilities has been calculated as $62 \%$ upon the assumption that the lease period is 30 years, the interest rate is $10 \%$ and 15 years of the life cycles have been consumed, the ratio of the unrecorded assets to the unrecorded liabilities has been calculated as $72 \%$ upon the assumption that the lease period is 25 years, the interest rate is $10 \%$ and $40 \%$ of the life cycles have been consumed and as a result, the average of these two ratios has been taken and according to the results of the study in which the ratio of the unrecorded assets to the unrecorded liabilities has been accepted as $67 \%$, it has been detected that there shall be an increase of 785.8 million dollars in the assets of the company and this is equivalent to $10 \%$ of the total assets. In addition; in the event of the capitalization of the operating leases, it has been detected that the ratio of the return on asset shall decrease by $9 \%$ and the liabilities/equity shall increase by approximately $30 \%$.

Imhoff et. al. (1997) have aimed to reveal how the operating lease capitalization shall affect both the operating profit and the net profit because the impacts of the operating leases may be significant on the income statement. The results of the study show that the unrecorded operating leases have an important impact on the standard profitability scales.

In the study conducted by Beattie et.al. (1998), they have aimed to assess the impacts of the decapitalized operating leases of 232 listed companies that have been processed in the England stock market as of 1994 on the financial statements. As a result of the study, it has been detected that the unrecorded assets are $6 \%$ of the total assets and unrecorded long term liabilities are $39 \%$ of the liabilities reported on average. In addition, there shall be significant change in the ratios of profit margin, turnover of the assets, return on asset and the debt/equity and mostly the service sector shall be affected among the sectors.

Marşap (1999), examined the negative effect of decapitalized lease processes on financial statement in terms of liquidity, financial structure, profitability ratios, turnover rates of tangible fixed asset and fixed asset from lessee point of view and in terms of liquidity, operating rates, turnover rates of fixed asset and tangible fixed asset from lessor company point of view. The obtained results from the ratios were emphasized to be lower or greater than it should be and that misleading results were obtained. 
In their study, Bennett and Bradbury (2003) have aimed to determine the impact of the capitalization of the leases belonging to 38 companies listed in New Zealand Stock Exchange Market on the financial statements. In the study; the ratio of the unrecorded assets to the unrecorded liabilities has been calculated as $81 \%$ upon the assumption that the life cycle of the leased assets is 10 years, the interest rate is $10 \%$ and half of the lease life cycles of the assets have been consumed and in this situation, it has been concluded that there shall be an increase by $22.9 \%$ in the liabilities, an increase by $10.6 \%$ on average in the total liability/total asset ratio, a decrease by $8.7 \%$ in the return on asset ratio and a decrease by $14.2 \%$ in the current ratio.

In the study conducted by Goodacre (2003) for the purpose of revealing the importance of the lease in England retail sector and determining the potential impact on the balance sheet in the event that all the leases are shown in the balance sheet of the lessee, it has been expressed that the unrecorded operating lease liabilities are 3.3 times more than the liabilities submitted in the balance sheet, the operating lease assets are $28 \%$ of the total assets, the depreciation to be separated for the leased assets shall increase the operating profit approximately by $23 \%$ in the event of the capitalization of the operating leases and the profit after the taxes shall decrease approximately by $7 \%$.

Duke and Hsieh (2006) have used the assumptions taking place in the studies of Imhoff et.al. $(1991,1997)$ for the purpose of calculating the impacts of the capitalization of the operating leases of six American companies defined by The Wall Street Journal as the significant users of the unrecorded lease liabilities. Upon the assumption that the interest rate is $10 \%$ and only 15 years is remaining from the life cycle of the leased asset; it has been detected that in the event that the value of the leased assets are equal to $70 \%$ of the value of the unrecorded lease liabilities, the liability/equity ratio shall increase to 4.532 from 1.609 and therefore, it shall increase more than twice, the return on asset ratio shall decrease to 0.047 from 0.076 and therefore, it shall decrease by $38 \%$. In addition; it has been determined that the unrecorded lease liabilities are as much as $89.5 \%$ of the reported liabilities on average and the unrecorded assets are as much as $39.4 \%$ of the reported assets.

Durocher (2008) has examined the impact of the reflection of the operating leases belonging to 100 companies having the highest revenue in 2002 and 2003 and whose securities have been traded in Canadian stock market on the balance sheet on the financial indicators under certain assumptions (interest rate, total life cycle of the lease/consumed life cycle/remaining life cycle and tax rate). The results have shown that the reflection of the operating leases on the balance sheet has caused to significant increases in the liabilities and assets and for this reason, there shall be a significant increase in the ratio of liability/asset and a significant decrease in the current ratio and the impacts of the operating leases on the income statement are less important. In addition; in the study, it is stated that the capitalization of the operating leases shall have important impacts on return on asset, return on equity and/or profit per share in only three sectors (merchandising and lodging, oil and gas, financial service).

Branswijck et.al. (2011) have stated that the most important change is the elimination of the distinction between financial lease and operating lease in the draft study conducted by IASB and FASB published in 2010. In the study, they have examined the possible impacts of the related changes on the companies having activities in Belgium and Holland. Consequently; in the event of the capitalization of the operating leases, they have determined that the liability/equity ratio, return on asset and current ratio are negatively affected. In addition; they have detected that these impacts occurring in the financial ratios show differences between the sectors.

In the study conducted by Kostolansky and Stanko (2011) for the purpose of measuring the impacts of new lease standard on the ratios and financial positions of the industries and companies represented in S\&P 100 under various discounting ratios $(3 \%, 6 \%, 9 \%)$, it has been detected that in the event of the reflection of the operating leases on the balance sheet, (1) there has been significant changes in the total liability/total asset and return on asset ratios of the companies and (2) the retail sector is the mostly affected sector with $(43.16 \%)$ in the total liabilities, $(20.3 \%)$ in the total assets and $(14.77 \%)$ with the highest increase in total liability/total asset, (13.94\%) with the highest decrease in the return on asset in sectoral context. 
Singh (2012) has examined the financial ratios of the companies having activities in the restaurant and retail sectors between the years 2006-2008 for the purpose of examining the impacts of the draft text. Consequently; it has been stated in the study that (1) both sectors shall be affected from these changes in significant levels, (2) retail sector shall be affected more than the restaurant sector and (3) the magnitude of the companies is an important factor in this impact.

In the study conducted by Bostwick et.al. (2013) in which it has been aimed to determine the impacts of the capitalization of the leases belonging to five companies selected from five different sectors, he has compared and analogized the financial statement components (assets, liabilities, equity and net profit) and the performance scales (total liabilities/assets, total liabilities/equity, long term liabilities/equity, return on asset, return on equity) both in terms of the companies and the capitalization methods. In the study, it has been determined that the retail companies are the ones that are affected from the capitalization of the leases in the highest/lowest way.

In the study conducted by Fitó et.al. (2013) for the purpose of assessing the potential impacts of the reflection of the operating leases of 52 listed companies are processed in the Spanish stock market in the period 2008-2010 on the balance sheet, it has been detected that the impact of the leases on the financial ratios is statistically significant, and the retail and energy sectors are the mostly affected sectors when the sectors are taken into consideration.

Tai (2013) has examined the impacts of the draft published in 2010 by IASB and FASB on two companies having activities in fast-food sector in Hong Kong. The ratio of the unrecorded assets to the unrecorded liabilities has been calculated as $85 \%$ upon the assumption that the lease period is 10 years, the interest rate is $6 \%$ and $40 \%$ of the life cycles of the assets have been consumed, the ratio of the unrecorded assets to the unrecorded liabilities has been calculated as $79 \%$ upon the assumption that the lease period is 12 years, the interest rate is $6 \%$ and $50 \%$ of the life cycles of the assets have been consumed and as a result, the average of these two ratios has been taken and according to the results of the study in which the ratio of the unrecorded assets to the unrecorded liabilities has been accepted as $82 \%$, it has been expressed that the capitalization of the operating leases shall cause to serious changes both on the return on asset and the liability/equity ratios.

Bohušová (2015) has focused on the results of showing the operating leases on the financial statements after capitalization following the changes to be made on IAS17. As a result, he has expressed that the related changes shall have important effects on the financial statements and financial ratios.

In the study conducted by Ericson and Skarphagen (2015), they have examined how the capitalization of the operating leases of 55 companies open to public and having activities in Stockholm NASDAQ OMX in Switzerland shall affect the debt and profitability ratios. As a result of the study, they have determined that a new lease standard not having any distinction of operating lease has an important effect on the liability/equity, equity/asset, profit margin, return on equity and return on asset.

As a result of the study conducted by Wong and Joshi (2015) for the purpose of examining the impact of the capitalization of the leases in the companies having activities in Australian Stock Exchange Market on the financial ratios and financial statements, although they have detected that the capitalization of the leases has a significant impact on the financial statements of the companies, they have determined that the changes in assets, liabilities and equity are not as important as the changes taking place in the previously conducted studies. In addition, it has been detected in the study that in the event of the reflection of the leases on the balance sheet; liability/equity, liability/asset and return on asset shall significantly change and the return on equity shall slightly change.

In the study conducted by Öztürk (2016), Öztürk handled the differences between IAS 17 standard and IFRS 16 standard in terms of lessee and lessor and evaluated the effect of all lease processes being reported as financial lease on airline sector in terms of liquidity and financial structure. As a result of the evaluation made within the framework of fleet structures and financial structures of the examined airlines, 
it is expected that Lufthansa will be affected at low level, Turkish Airlines will be affected at medium level and Pegasus will be affected at high level in case all leases are reported as financial lease.

In the study conducted by Sarı et. al. (2016), they aimed to indicate the effect of IFRS 16 on financial statements and financial ratios of companies in retailing sector that are active in Borsa istanbul. The results indicate that IFRS 16 will have a statistically significant effect on some of the financial ratios (debt/asset, debt/equity, return on assets and return on equity) and for 2010 - 2013. In addition; the results show that the new lease standard would have a significant effect on the financial indicators (total assets and total liabilities) in the years 2010 and 2011.

\section{What does IFRS 16 bring?}

The leases have been classified and accounted as financial or operating lease in terms of the lessee or lessor in the previous accounting model regarding the recognition of the leases under IAS 17 which has been criticized by the financial statement users due to the fact that the lease processes are not always reliably submitted. The most important one of them has been the fact that the lessees have not needed to account their assets and liabilities stemming from the operating leases of the lessee (IFRS 16: par. IN5).

Both International Accounting Standards Board (IASB) and Financial Accounting Standards Board (FASB) have worked on an accounting standard that shall reflect all the lease processes on the balance sheet for the purpose of meeting the principle of faithful representation within the direction of the liabilities stemming from the lease processes to reflect the amount that should be reported on the balance sheet (IASB 2016c: par. BC3).

IFRS 16 shall terminate the application of the following standards (IFRS16: par. IN3):

- "IAS 17 Leases,

- IFRIC 4 Determining whether an Arrangement contains a Lease,

- SIC-15 Operating Leases-Incentives,

- SIC-27 Evaluating the Substance of Transactions Involving the Legal Form of a Lease".

IFRS 16 lease accounting requires the recognition of the rights and liabilities of the lessee stemming from the leases in the assets and resources. The new approach has revealed the result of submitting the assets and resources of the lessee in a more reliable way together with the increasing clearness. In addition; IFRS 16 shall ensure a more transparent submission of the financial leverage and working capital of the lessee (IFRS 16: par. IN1-IN6). No significant and different liability has been brought in IFRS 16 when compared to IAS 17 in terms of the lessor. The lessor shall still continue to classify its leases as financial or operating leases (IFRS16: par. IN14).

A lessee operation applying IFRS 16 (IASB, 2016a: 12);

- Should show the assets and liabilities regarding the leases on the balance sheet and calculate its future lease payments on present values

- Should recognise depreciation of lease assets and interest on lease liabilities in the income statement over the lease term

- Should separate its leases according to the present value of total cash payments and should also separate the interest expenses in the cash flow statement (belonging to the financial or operating leases).

There is no difference between IFRS 16 and IAS 17 in terms of the definition of the lease. IFRS 16 guides in the issue of how the changes shall be applied. Actually, the change develops on the concept of control. IFRS 16 covers the explanations related to whether the content of a contract including lease gives the right of using the asset to the users during the period they use (IASB, 2016a: 11).

Important issues regarding IFRS 16 are as follows (IASB, 2016b: 1); 
- The desiring companies shall be able to apply IFRS 16 standard on the condition that they apply IFRS 15 standard.

- The most important change brought by the new standard is the provision of the transparency of all the leases on the balance sheet of the companies and it shall increase the transparency of the assets and liabilities.

- With IFRS 16, there is not going to be any need for the distinction of the leases as operating or financial leases in terms of the lessee and all the leases shall be classified as financial lease.

- The assets with a period shorter than 12 months and the assets with low value such as personal computers shall be exempt from these liabilities.

First-time Adoption of International Financial Reporting Standards;

When a lessee adopting first-time recognizes lease liabilities and right-of-use assets, it may apply the following approach to all of its leases (IFRS 16: par. D9B):

(a) "measure a lease liability at the date of transition to IFRSs. A lessee following this approach shall measure that lease liability at the present value of the remaining lease payments, discounted using the lessee's incremental borrowing rate at the date of transition to IFRSS.

(b) measure a right-of-use asset at the date of transition to IFRSs. The lessee shall choose, on a lease-bylease basis, to measure that right-of-use asset

at either:

(i) its carrying amount as if IFRS 16 had been applied since the commencement date of the lease, but discounted using the lessee's incremental borrowing rate at the date of transition to IFRSs; or

(ii) an amount equal to the lease liability, adjusted by the amount of any prepaid or accrued lease payments relating to that lease recognised in the statement of financial position immediately before the date of transition to IFRSs.

(c) apply IAS 36 to right-of-use assets at the date of transition to IFRSs".

It is expected that IFRS 16 shall have impacts on the balance sheet, income statement and cash flow statement of the companies with the effect of the unrecorded leases of the companies (IASB, 2016a: 12). It is thought by IASB that IFRS 16 shall cause to important effects on the financial ratios of the companies. If a company classifies its leases as financial lease, it is considered that this shall not cause to very significant changes on the financial ratios. In any case, it is considered that the related standard shall have significant impacts on the financial ratios in the companies classifying their leases as operating lease.

The expected changes have been summarized in the following table.

Table 1. Change on Key Financial Metrics (IASB, 2016a: 52)

\begin{tabular}{|l|l|}
\hline \multicolumn{1}{|c|}{ Change } & \multicolumn{1}{c|}{ Effect } \\
\hline $\begin{array}{l}\text { Recognition of an asset that was } \\
\text { previously unrecognized }\end{array}$ & Higher asset base, which will affect ratios such as asset turnover. \\
\hline $\begin{array}{l}\text { Recognition of a liability that } \\
\text { was previously unrecognized }\end{array}$ & $\begin{array}{l}\text { Higher financial liabilities, which will affect financial leverage } \\
\text { (gearing). }\end{array}$ \\
\hline $\begin{array}{l}\text { Recognition of depreciation and } \\
\text { interest instead of operating } \\
\text { lease expense }\end{array}$ & $\begin{array}{l}\text { Higher operating profit (because interest is typically excluded from } \\
\text { operating expenses). Similarly, profit measures that exclude } \\
\text { interest and depreciation but include operating lease expense, } \\
\text { such as EBITDA (Earnings Before Interest Taxes Depreciation and } \\
\text { Amortisation), will be higher than when applying IAS 17. }\end{array}$ \\
\hline
\end{tabular}


M. Ozturk - M. Sercemeli

In Table 2, the impacts of the unrecorded leases on the frequently used financial ratios are shown.

Table 2. Effects on Key Financial Ratio (IASB, 2016a: 53)

\begin{tabular}{|c|c|c|c|c|}
\hline Ratio & $\begin{array}{c}\text { What it } \\
\text { measures }\end{array}$ & $\begin{array}{c}\text { Common method of } \\
\text { calculation }\end{array}$ & $\begin{array}{l}\text { Expected } \\
\text { effect }\end{array}$ & Explanation \\
\hline Leverage & $\begin{array}{l}\text { Long-term } \\
\text { solvency }\end{array}$ & Liabilities/ Equity & Increase & $\begin{array}{l}\text { Increase because financial liabilities } \\
\text { increase (and equity is expected to } \\
\text { decrease). }\end{array}$ \\
\hline $\begin{array}{l}\text { Interest } \\
\text { cover }\end{array}$ & $\begin{array}{l}\text { Long-term } \\
\text { solvency }\end{array}$ & EBITDA/Interest expense & Depends & $\begin{array}{l}\text { EBITDA will increase applying IFRS } \\
16 \text { as will interest expense. The } \\
\text { change in the ratio will depend on } \\
\text { the characteristics of the lease } \\
\text { portfolio. }\end{array}$ \\
\hline $\begin{array}{l}\text { Current } \\
\text { ratio }\end{array}$ & Liquidity & $\begin{array}{l}\text { Current assets/Current } \\
\text { liabilities }\end{array}$ & Decrease & $\begin{array}{l}\text { Decrease because current lease } \\
\text { liabilities increase while current } \\
\text { assets do not. }\end{array}$ \\
\hline $\begin{array}{l}\text { Asset } \\
\text { turnover }\end{array}$ & Profitability & Sales / Total assets & Decrease & $\begin{array}{l}\text { Decrease because lease assets will } \\
\text { be recognised as part of total assets }\end{array}$ \\
\hline $\begin{array}{l}\text { EBIT } \\
\text { (Earnings } \\
\text { before } \\
\text { interest } \\
\text { and } \\
\text { taxes)/ } \\
\text { Operating } \\
\text { profit }\end{array}$ & Profitability & $\begin{array}{l}\text { Various methods-Profit } \\
\text { that does not consider } \\
\text { earnings from } \\
\text { investments and the } \\
\text { effects of interest and } \\
\text { taxes }\end{array}$ & Increase & $\begin{array}{l}\text { Increase because the depreciation } \\
\text { charge added is lower than the } \\
\text { expense for off balance sheet leases } \\
\text { excluded. }\end{array}$ \\
\hline EBITDA & Profitability & $\begin{array}{l}\text { Profit before interest, } \\
\text { tax, depreciation and } \\
\text { amortisation }\end{array}$ & Increase & $\begin{array}{l}\text { Increase because expenses for off } \\
\text { balance sheet leases are excluded. }\end{array}$ \\
\hline $\begin{array}{l}\text { Profit or } \\
\text { loss }\end{array}$ & Profitability & As reported applying IFRS & Depends & $\begin{array}{l}\text { Depends on the characteristics of } \\
\text { the lease portfolio and the tax rate. }\end{array}$ \\
\hline $\begin{array}{l}\text { EPS } \\
\text { (Earnings } \\
\text { Per Share) }\end{array}$ & Profitability & $\begin{array}{l}\text { Profit or Loss / Number } \\
\text { of shares in issue }\end{array}$ & Depends & $\begin{array}{l}\text { Depends on the effect on profit or } \\
\text { loss, which depends on the } \\
\text { characteristics of the lease portfolio } \\
\text { and the effects on tax. }\end{array}$ \\
\hline $\begin{array}{l}\text { ROCE } \\
\text { (Return } \\
\text { on Capital } \\
\text { Employed) }\end{array}$ & Profitability & $\begin{array}{l}\text { EBIT / Equity plus } \\
\text { financial liabilities }\end{array}$ & Depends & $\begin{array}{l}\text { EBIT will increase applying IFRS } 16 \text { as } \\
\text { will financial liabilities. The change } \\
\text { in the ratio will depend on the } \\
\text { characteristics of the } \\
\text { lease portfolio. }\end{array}$ \\
\hline $\begin{array}{l}\text { ROE } \\
\text { (Return } \\
\text { on Equity) }\end{array}$ & Profitability & Profit or Loss / Equity & Depends & $\begin{array}{l}\text { Depends on the effect on profit or } \\
\text { loss, which in turn depends on the } \\
\text { lease portfolio }\end{array}$ \\
\hline $\begin{array}{l}\text { Operating } \\
\text { cash flow }\end{array}$ & Profitability & $\begin{array}{l}\text { Various methods-Cash } \\
\text { flow from operating } \\
\text { activities does not } \\
\text { include cash related to } \\
\text { equity and borrowings }\end{array}$ & Increase & $\begin{array}{l}\text { Increase because at least part of the } \\
\text { lease payments (those payments } \\
\text { relating to the principal) will be } \\
\text { moved to the financing section of } \\
\text { the cash flow statement. }\end{array}$ \\
\hline
\end{tabular}




\section{Methodology}

In this paper, financial data of the year 2015 of Pegasus Airline Company that operates in Turkey have been used in the case analysis conducted for the purpose of detecting the impacts of IFRS 16 on the statement of financial position and financial ratios. The reason why Pegasus Airline Company is preferred is that the companies having activities in airline, retail and travel/leisure sectors have been expected to be more affected when compared to other companies (IASB 2016b: 2) and the company attains almost all of its planes (more than half) via lease and it records and reports the majority of its leases as operating lease.

Pegasus Airline Company is an airline company whose headquarters is in Istanbul and that has adopted the low cost model. The company realizes flight activities by its own planes, planes obtained by financial lease and planes obtained by operating lease. The number of planes in company fleet are shown in Table 3.

Table 3. Number of Planes in Fleet of Pegasus Airlines on Yearly Basis

\begin{tabular}{|l|c|c|c|c|}
\hline & $\begin{array}{c}\text { Own } \\
\text { planes }\end{array}$ & $\begin{array}{c}\text { Planes Obtained } \\
\text { by Financial Lease }\end{array}$ & $\begin{array}{c}\text { Planes Obtained } \\
\text { by Operating Lease }\end{array}$ & Total \\
\hline 31 December 2013 & 1 & 27 & 21 & $\mathbf{4 9}$ \\
\hline 31 December 2014 & 3 & 25 & 27 & $\mathbf{5 5}$ \\
\hline 31 December 2015 & 3 & 25 & 39 & $\mathbf{6 7}$ \\
\hline
\end{tabular}

In the study, the method of constructive lease capitalization developed by Imhoff et.al. (1991) has been used in the capitalization of the unrecorded leases of Pegasus Airline Company. The method developed by Imhoff et.al. (1991) has been commonly accepted and applied for the purpose of measuring the impacts of the capitalization of the leases on the financial statements and financial ratios in the studies conducted by Beattie et.al. (1998), Bennet and Bradbury et.al. (2003) (2009), Singh (2012), Branswijck et.al. (2011), Tai (2013), Wong and Joshi (2015).

In the method suggested by Imhoff et.al. (1991), it is necessary to detect the unrecorded lease liabilities, unrecorded leased assets, the tax savings and equity elements to be provided from the capitalization of the lease for the purpose of being able to determine the impacts of the leases on the financial figures and on some key financial ratios in the event of reporting the operating leases as financial lease.

\subsection{Estimating of Unrecorded Lease Liabilities}

The liabilities associated with the assets subject to the leases in the lease proceedings in IFRS 16 represent the present value of the lease payments that have not been paid in the date submitted for the usage of the lessee by the lessor regarding the asset subject to the issue (IFRS 16:IN12). The detection of the present value requires the reduction of the future lease payments to its present value within the frame of a certain interest rate. The operating lease liabilities of the company as of 2015 are shown in Table 4.

Table 4. The Non-cancellable Operating Lease Liabilities of Pegasus Airline Company

\begin{tabular}{|l|c|}
\hline Years & $\begin{array}{c}\text { The Non-Cancellable Operating } \\
\text { Lease Liabilities }\end{array}$ \\
\hline Less than 1 year & $400,006,430$ \\
\hline Between 1 - 5 years & $1,311,457,028$ \\
\hline Over 5 years & $327,309,414$ \\
\hline Total & $\mathbf{2 , 0 3 8 , 7 7 2 , 8 7 2}$ \\
\hline
\end{tabular}


As it could be understood from Table 4, it has been observed that the payments of the Company regarding its non-cancellable operating lease liabilities in the financial statement footnotes of the operating reports of the company have not been submitted yearly and the lease liabilities have been grouped as $0-1$ year, 1-5 years and more than 5 years. It is necessary to know the amount and period of the operating leases of the company as of years for the purpose of being able to calculate the present value of the operating lease liabilities. Because the operating lease liabilities of the company cannot be reached yearly, it has been assumed that the payments between $1-5$ years are equal $(1,311,457,028 / 5=262,291,406)$ and regarding the payments in more than 5 years, the liabilities of the remaining two years are also equal $(327,309,414 / 2=163,654,707)$ because the operational lease contracts of the company are utmost 8 years. Another assumption regarding the calculation of its present value is the interest rate. According to IFRS 16, the lessee should determine lease liabilities of the unpaid lease payments at the beginning date with their present value. If the implicit interest rate used in the financial lease of the lease payments could be detected, it should be discounted with this ratio. If this ratio cannot be detected, it could use the alternative liability interest ratio of the company (IFRS 16: par. 22-29). Because the implicit interest rate and alternative liability interest rate of the company cannot be detected, the interest rate has been considered as $10 \%$. The similar rate has been used in similar studies (Beattie et.al., 1998; Imhoff et.al., 1991; Duke et.al., 2009; Wong and Joshi, 2015). The present value of the operating leases of Pegasus Airline Company are presented in Table 5.

Table 5. Present Value of Pegasus Airline Company Operating Leases

\begin{tabular}{|c|c|c|c|}
\hline Years & $\begin{array}{c}\text { Minimum Lease } \\
\text { Payment }\end{array}$ & $\begin{array}{c}10 \% \text { Present Value } \\
\text { Factor }\end{array}$ & $\begin{array}{c}\text { Present Value of Cash } \\
\text { Outflows }\end{array}$ \\
\hline 2016 & $400,006,430$ & 0.9091 & $363,645,846$ \\
\hline 2017 & $262,291,406$ & 0.8264 & $216,757,618$ \\
\hline 2018 & $262,291,406$ & 0.7513 & $197,059,533$ \\
\hline 2019 & $262,291,406$ & 0.6830 & $179,145,030$ \\
\hline 2020 & $262,291,406$ & 0.6209 & $162,856,734$ \\
\hline 2021 & $262,291,406$ & 0.5645 & $148,063,499$ \\
\hline 2022 & $163,654,707$ & 0.5132 & $83,987,596$ \\
\hline 2023 & $163,654,707$ & 0.4665 & $76,344,921$ \\
\hline \multicolumn{3}{|c|}{ Estimated Unrecorded Debt } & $1,427,860,777$ \\
\hline
\end{tabular}

After off-balance sheet lease liabilities are detected, it is necessary to calculate the assets leased as off-balance sheet. The value of the off-balance sheet assets is dependent on the cash flow, alternative liability interest rate of the lessee and the remaining life cycle of the leases. In addition; it is necessary to know the total life cycle of the leased assets and the depreciation method for the determination of the off-balance sheet assets. In addition, some assumptions have been made because the total life cycle of the leased asset and the applied depreciation method have not been known. Due to the unknown situation of the elements necessary to be known for the determination of the off-balance sheet assets and the conducted assumptions, the estimation of the off-balance sheet assets is harder than the estimation of the off-balance sheet liabilities and the error in the estimated value of the off-balance sheet assets may exceed $\pm 5 \%$. Despite this fact, it is possible that the estimate shall be within the acceptable limits again and it shall be better than neglecting the effects of the constructive capitalization (Imhoff et.al. 1991, 55-56).

In Table 6, the relation between the off-balance sheet liabilities and assets are submitted within time frame according to the method suggested by Imhoff (1991) for the estimation of the off-balance sheet assets. The percentages in the Table 6 show the off-balance sheet operating lease assets as a percentage of the remaining off-balance sheet operating lease liabilities in certain points of the weighted average remaining useful life cycles of the assets (Imhoff et.al., 1991: 56). 

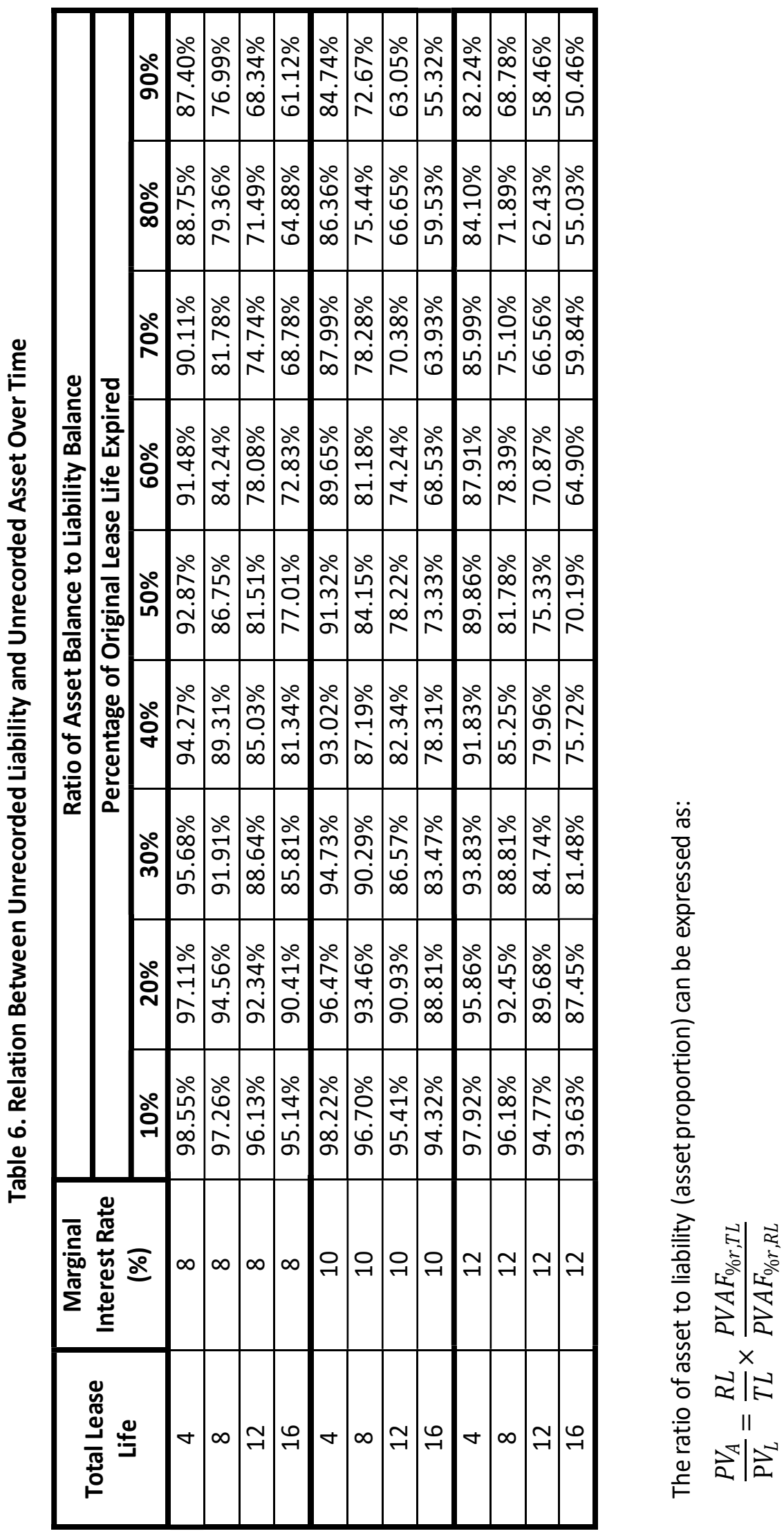
Some assumptions have been made while forming the table:

- Straight-line depreciation method has been used for the assets.

- Both off-balance sheet lease assets and the off-balance sheet lease liabilities are equal to the present value of the future lease payments at the beginning of the lease; in other words, $100 \%$ (When lease process is realized same amount of increase will occur in assets and liabilities of the company).

- Both off -balance sheet lease asset and the off-balance sheet lease liabilities are equal to zero when the lease payments are completed.

The ratio of the assets to the liabilities have been calculated in different points of the lease life cycle has been calculated and shown in Table 6 upon the assumptions that the total life cycle of the lease, interest rate and the consumption of the lease life.

After the first payment belonging to the operating lease liabilities is realized, all the percentages in Table 5 are below $100 \%$ because the unpaid balance of the off-balance sheet liabilities are more when compared to the balance of the off-balance sheet operating lease assets. In other words; the assets leased as off-balance sheet decrease more rapidly than the off-balance sheet lease liabilities. The reason for this is that the majority of the beginning payments of the lease consists of the interest payments and the minority of them consist of capital payments and therefore, the book value of the leased assets shall be less than the book value of the lease liabilities because depreciation deduction shall decrease the value of the asset in a higher ratio than reduction in the capitalization of the liabilities (Shing, 2012: 7, Imhoff, 1991: 57).

Because Pegasus Airline Company realizes its operating lease contracts between 1-8 years, upon the assumption that the lease period is 8 years, interest rate is $10 \%$ and $50 \%$ of the lease life cycles of the assets have been consumed;

$$
\frac{P V_{A}}{\mathrm{P} V_{L}}=\frac{8-(8 * \% 50)}{8} \times \frac{P V A F_{\% 10,8}}{P V A F_{\% 10,4}}
$$

Net book value of the off-balance sheet assets has been calculated as $84.15 \%$ of the off-balance sheet lease liabilities. The difference of $15.85 \%$ between the off-balance sheet lease liabilities and assets represents the additional lease expenses. Net profit after the tax and equity shall decrease together with the corporate income tax rate (20\%). The amounts that shall change in the balance sheet after the capitalization of the unrecorded operating leases are shown below.

\section{Impact of Constructive Capitalization on Pegasus Airline Company Balance Sheet}

Change of Pegasus Airline Company Balance Sheet in 2015

\begin{tabular}{|c|c|c|c|}
\hline \multicolumn{2}{|l|}{$\underline{\text { ASSETS }}$} & \multicolumn{2}{|l|}{$\underline{\text { LIABILITY }}$} \\
\hline Unrecorded Lease Assets* & $1,201,544,844$ & Unrecorded Lease Liabilities & $1,427,860,777$ \\
\hline & & Tax Deductions** & $(45,263,187)$ \\
\hline & & LIABILITIES (NET EFFECT) & $1,382,597,590$ \\
\hline & & EQUITY & $(181,052,746)$ \\
\hline & $\underline{\underline{1,201,544,844}}$ & & $\underline{\underline{1,201,544,844}}$ \\
\hline
\end{tabular}

* Unrecorded Lease Assets $=1,427,860,777 * 84.15 \%=1,201,544,844 \mathrm{TL}$

** Tax Deductions $=(1,427,860,777-1,201,544,844) * 20 \%=45,263,187 \mathrm{TL}$ 
If the company reports its unrecorded leases under the assumptions mentioned before, there shall be an increase of 1,201,544,844 TL in its assets, an increase of 1,382,597,590 TL in its liabilities and a decrease of $181,052,746 \mathrm{TL}$ in its equity.

The statement information of the balance sheet reported for the year 2015 and the statement information of the company after the capitalization take place in Table 7.

Table 7. Financial Statement Summary of Pegasus Airline Company

\begin{tabular}{|l|l|l|l|l|}
\hline & 2015 Reported & Difference & $\begin{array}{l}\text { After } \\
\text { Capitalization }\end{array}$ & $\begin{array}{l}\text { Change } \\
\text { (\%) }\end{array}$ \\
\hline Total Assets & $4,098,097,252$ & $1,201,544,844$ & $5,299,642,096$ & $29.3 \%$ increase \\
\hline Total Liabilities & $2,645,365,623$ & $1,382,597,590$ & $4,027,963,213$ & $52.2 \%$ decrease \\
\hline Equity & $1,452,731,629$ & $(181,052,746)$ & $1,271,678,883$ & $12.5 \%$ decrease \\
\hline Net Income & $111,863,873^{*}$ & & & \\
\hline
\end{tabular}

* No change has been estimated to occur net income because the impacts of the capitalization on the income statement have not been included in the scope of the study.

An increase of $52.2 \%$ has occurred in the liabilities of the company, a decrease of $12.5 \%$ has occurred in the equity of the company and an increase of $29.3 \%$ has occurred in the total assets of the company following the capitalization of the unrecorded leases. Because these ratios do not give any sufficient meaning all alone in the issue of the financial position of the company, it is necessary to consider the change in the financial ratios which is an important tool in the measurement and analysis of the performance of the company and which is also used for the purpose of comparing the financial position and operating results of the company to the results of other companies in the same or different sector and within itself. The impacts of the capitalization on some financial ratios are submitted in Table 8.

Table 8. Impact of Constructive Capitalization on Financial Ratios

\begin{tabular}{|c|c|c|c|c|}
\hline & Debt/Equity & Debt/Asset & Return on Asset (ROA) & Return on Equity (ROE) \\
\hline 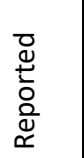 & $\frac{2,645,365,623}{1,452,731,629}=1.82$ times & $\frac{2,645,365,623}{4,098,097,252}=65 \%$ & $\frac{111,863,873}{4,098,097,252}=3.2 \%$ & $\frac{111,863,873}{1,452,731,629}=7.7 \%$ \\
\hline 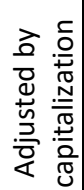 & $\frac{4,027,963,213}{1,271,678,833}=3.17$ times & $\frac{4,027,963,213}{5,299,642,096}=76 \%$ & $\frac{111,863,873}{5,299,642,096}=2.1 \%$ & $\frac{111,863,873}{1,262,768,033}=8.9 \%$ \\
\hline 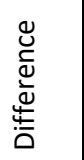 & $75.3 \%$ increase & $16.9 \%$ increase & $34.4 \%$ decrease & $15.6 \%$ increase \\
\hline
\end{tabular}


The highest change (75.3\%) has occurred in liabilities/equity ratio when the unrecorded assets have been capitalized under the assumptions mentioned before. As a result of the capitalization method, capitalization on the liabilities/equity has shown a negative impact because the liabilities of the company have increased and its equity has decreased. The ratio of liabilities/equity shows the relations between the liability of the company provided via debt and the capital given by the owners or partners of the company. In the event that the ratio is above the desired level, this shows that the company is financed by the third parties rather than the owners of the company. The higher the ratio is, the higher the risk exists for the company. An increase of $16.9 \%$ has been observed in the total liability/total asset ratio which is another debt ratio of the company and which is also called as leverage ratio after the capitalization. Leverage ratio shows at what percent the assets are financed by the liabilities and the highness of the ratio is the sign for the fact that the company is financed in a risky way.

In the event of the capitalization of the operating leases, the lease expenses belonging to the operating leases shall not been shown in the income statement and depreciation shall be left for the leased assets. Because the depreciation to be left for the assets leased as a result of the capitalization shall be less than the lease expenses of the operating leases, the operating profit shall increase, an increase shall occur in the liabilities and the interest expense belonging to the liabilities shall also cause to the decrease of the net profit. In other words; net profit shall increase as much as the lease expenses belonging to the operating expenses and it shall decrease as much as depreciation and interest expense. However; because the impacts of the capitalization on the balance sheet have been examined in our study, it has been assumed that net profit has not changed. Because the capitalization of the operating leases shall decrease the equity under the assumption that net profit has not changed, the ratio of the return on equity shall increase by $15.6 \%$ and the ratio of return on asset shall decrease by $34.4 \%$ because an increase shall occur in the asset.

\section{Conclusion}

Companies may acquire the necessary economic securities by the means of purchasing and leasing in order to carry out their activities. Limited resources and high cost of equity direct the companies to lease the economic securities instead of purchasing them. According to the existing regulations, general lease proceedings are basically classified as finance lease and operating lease. In the financial lease transaction, in the commencement of the lease term, the lease amounts to be paid in the future are indicated as an asset in the assets of the lessee and as debt in the liability of the lease; whereas in the operating lease, the socalled asset is not visible in the balance sheet of the lessee and the lease payments are reflected as expense in the income statement. Thus; the companies that indicate their leases as operating leases acquire unrecorded financing. Together with the unrecorded financing, the companies decrease or conceal the risks that they may face with by extracting their assets and liabilities and also their incomes and expenses from the financial statement. In other words, a strong image of the financial structure of their companies is provided with the help of the unrecorded finance. This condition substantially abolishes the possibility of making comparison between the companies by the savings owners when they make their preferences and thus, it may result in the fact that two enterprises with the same features are perceived as quite financially different from each other by investors, thereby, which may result in the situation that the investment decisions are shaped quite differently by the investors. Different assessment of two leases that are essentially the same has caused the standard determiners and other concerned people to start studies regarding the preparation of the amendments related to the accounting of the leases and IFRS 16 being the new lease standard was published.

The primary difference between the standard IFRS 16 and IAS 17 is the state of the fact that in IFRS 16 all lease transactions are reported as a financial lease transaction by the lessee regardless of whether the leasing is finance lease or operating lease and the fact that the disclosures of financial statements have been developed in a way that they shall reflect the cash flows, the financial performance and the financial position of the lessee or the lessor. In other words, IFRS 16 shall cause to the termination of the distinction between operating and financial lease, capitalization of the lease contract and the finalization of the unrecorded financing for long-term leases. 
Within this scope, this study has been conducted for the purpose of examining the impacts of the capitalization of operating leases; in other words, IFRS 16, on the statement of financial position and the selected financial analysis ratios of Pegasus Airline Company Constructive lease capitalization method developed by Imhoff et.al. 1991 has been applied in the capitalization of the operating leases of the company and it has been detected that there shall be an increase by $52.2 \%$ in the liabilities of the company, a decrease by $12.5 \%$ in the equity of the company and an increase by $29.3 \%$ in the total assets of the company upon the assumption that the lease period is 8 years, interest rate is $10 \%$ and half of the lease life cycles of the assets have been consumed. The total liability/equity ratio of the company shall significantly change in the event of the capitalization of its operating leases. The reason for this is that there is a serious increase in the liabilities and there is a decrease in the equity. The ratio of total liability/total assets shall change less when compared to the ratio of total liability/equity because there shall be an increase in both the liabilities and total assets. These results indicate the results similar to other studies conducted in the literature.

Consequently; the financial positions of the lessee companies having unrecorded leases shall change when their lease contracts are capitalized and there shall be distortions (decrease in the return on asset, increase in the liabilities and increase in liability/equity) in all the financial ratios affected from the capitalization. The magnitude of this impact could be said to change depending on the usage density of the operating lease in the companies and also depending on the sector they are in.

\section{End Notes}

${ }^{1}$ The related company leases the majority of its company planes and keeps them off the balance sheet by assessing more than half of its leases as operating lease.

${ }^{2}$ Listed companies in Borsa istanbul should publish their financial reports in accordance with the Turkish Accounting Standards. These standards are the completely adapted versions of the international financial reporting standards into Turkish. Therefore; IAS 17 standard is respected in the proceedings regarding the lease processes.

\section{References}

Beattie, V., Edwards, K., \& Goodacre, A. (1998). The impact of constructive opareting lease capitalisation on key accounting ratios. Accounting and Business Research, 28(4), 233-254.

Bennett, B. K., \& Bradbury, M. E. (2003). Capitalizing non-cancelable operating leases. Journal of International Financial Management and Accounting, 14 (2), 101-114.

Bohušová, H. (2015). Is capitalization of operating lease way to increase of comparability of financial statements prepared in accordance with IFRS and US GAAP?. Acta Universitatis Agriculturae et Silviculturae Mendelianae Brunensis, 63(2), 507-514.

Bostwick, E. D., Fahnestock, R. T., \& O'Keefe, W. T. (2013). Effects of lease capitalization techniques on key measures of financial performance. Journal of Finance \& Accountancy, 12, 91-102.

Branswijck, D., Longueville, S., \& Everaert, P. (2011). The financial impact of the proposed amendments to IAS 17: Evidence from Belgium and the Netherland. Accounting and Management Information Systems, 10(2), 275-294.

Duke, J. C., \& Hsieh, S-J (2006). Capturing the benefits of operating and synthetic leases. The Journal Corporate Accounting \& Finance, 18(1), 45-52.

Durocher, S. (2008). Canadian evidence on the constructive capitalization of operating leases. Accounting Perspectives, $7(3), 227-256$.

Ericson, J., \& Skarphagen, R. (2015). Capitalization of operating lease and its impacts on financial ratios. Master Thesis, Jörköping University Jörköping International Business School.

Fitó, M. À., Moya, S., \& Orgaz, N. (2013). Considering the effects of operating lease capitalization on key financial ratios. Spanish Journal of Finance and Accounting, 42(159), 341-369.

Goodacre, A. (2003). Operating lease finance in the UK retail sector. The International Review of Retail, Distribution and Consumer Research, 13 (1), 99-125. 
IAS 17 Leases Standard. December, 1997.

IASB, (2016a). Effects analysis, IFRS 16 Leases. http://www.ifrs.org/Current-Projects/IASBProjects/Leases/Documents/IFRS_16_effects_analysis.pdf. Accessed 02.02.2016.

IASB, (2016b). Fact sheet - IFRS 16 Leases. http://www.ifrs.org/current-projects/iasbprojects/leases/documents/leases-fact-sheet january2016.pdf. Accessed 29.02.2016.

IASB, (2016c). IFRS 16 leases basis for conclusions. IFRS Foundation Publications Department, London, United Kingdom.

IFRS 16 Leases Standard. IFRS Foundation Publications Department, London, United Kingdom. January, 2016.

Imhoff, E. A., Lipe, R. C., \& Wright D. W. (1997). Operating leases: Income effects of constructive capitalization. Accounting Horizons, 11(2), 12-32.

Imhoff, E. A., Lipe, R. C., \& Wright, D. W. (1991). Operating leases: Impact of constructive capitalization. Accounting Horizons, 5 (1), 51-63.

Kostolansky, J., \& Stanko, B. (2011). The joint FASB/IASB lease projects: Discussion and industry implications. Journal of Business \& Economics, 9 (9), 29-35.

Marşap, B. (2009). Finansal kiralama işlemlerinin mali tablolarda gösterilmesi ve analizi. Muhasebe Bilim Dünyası Dergisi, 1(4), 97-108.

Öztürk C. (2016). UFRS 16 kiralama işlemleri standardının eski UMS 17 standardı ile karşılaştırılması ve Almanya ve Türkiye'de hisse senetleri halka açık olan hava yolu şirketlerinin finansal durumuna etkisi. Muhasebe Bilim Dünyası Dergisi, 18(1), 1-50.

Sarı, E., S., Altintaş, T.\&Tas, N. (2016). The effect of the IFRS 16: Constructive capitalization of operating leases in the Turkish retailing sector. Journal of Business, Economics and Finance, 5 (1), 138-147.

Singh, A. (2012). Proposed lease accounting changes implications for the restaurant and retail industries. Journal of Hospitality \& Tourism Research, 36 (3), 335-365.

Tai, B. Y. (2013). Constructive capitalization of operating leases in the Hong Kong fast-food industry. International Journal of Accounting and Financial Reporting, 3(1), 128-142.

White, E. (2015). Global leasing report. White Clark Group. http://www.whiteclarkegroup.com/downloads/353/wcg_global_leasing_report_2015_public_final.pdf. Accessed 13.04.2016.

Wong, K., \& Joshi, M. (2005). The impact of lease capitalisation on financial statements and key ratios: Evidence from Australia. Australasian Accounting, Business and Finance Journal, 9(3), 26-44. 
This Page Intentionally Left Blank 